\title{
Making meaningful musical experiences accessible using the iPad
}

\author{
Andrew R. Brown'1, Donald Stewart², Amber Hansen', Alanna Stewart ${ }^{2}$ \\ ${ }^{1}$ Queensland Conservatorium, Griffith University, Brisbane, Australia \\ ${ }^{2}$ School of Public Health, Griffith University, Brisbane, Australia
}

\begin{abstract}
In this chapter we report on our experiences using ubiquitous computing devices to introduce musicbased creative activities into an Australian school. The use of music applications on mobile tablet computers (iPads) made these activities accessible to students with a limited musical background and practicable in a general-purpose classroom setting. The activities were designed to be meaningful and contribute toward personal resilience in the students. We describe the approach to meeting these objectives and discuss results of the project. The chapter includes an overview of the ongoing project including its aims, objectives and utilization of mobile technologies and software with generative and networkable capabilities. Two theoretical frameworks informed the research design; the meaningful engagement matrix and personal resilience. We describe these frameworks and how they inform the activity planning. We report on the activities undertaken to date and share results from questionnaires, interviews, musical outcomes, and observation.
\end{abstract}

\section{Introduction}

This project builds on the authors' previous work with network music jamming systems [1] (Brown and Dillon 2007) and youth resilience [2] (Stewart et al. 2004). These research threads have come together in this project. Taking advantage of the ubiquitous nature of mobile computing devices (in particular of Apple's iPad), the project aims to provide school students who have no particular background in music, with access to the creative and well-being benefits of collaborative and personally expressive music making. This project takes a step forward from our previous network jamming research by using Apple's GarageBand software on the iPad rather than the our own jam2jam software on laptop and desktop computers. jam2jam was specifically written for our previous research on how technologies afford meaningful engagement with music. It was used in this capacity between 2002 and 2012. The main software features of jam 2 jam that support accessibility and engagement are 1) the use of generative music processes to enable participation by inexperienced musicians, 2) the ability for systems to be synchronized over a network facilitating coordination amongst users, either locally or at a distance, and 3) the ability to record music making activities and export these for sharing. These features are now present in GarageBand for iPad (and an increasing number of other commercial software for mobile computing hardware).

In our previous examination of developing resilience in school contexts, positive contributing factors included students developing a sense of autonomy and feelings of connectedness with peers and adults. We suggest that the scaffolding effect of generative music process can assist in promoting a sense of creative autonomy in inexperienced musicians and that the collaborative aspects of group music making can strengthen feelings of connectedness amongst peers. An aim of this project is to show how the principles of education and health-promotion developed in our previous research can transfer to the use of ubiquitous computing systems.

\subsection{Brief description of the project}

This project focuses on building and supporting young people's engagement and connectedness with their creative selves and to help build resilience through musical collaboration and success. Working with a school of Indigenous Australian students (the Murri school) based in Brisbane, Australia we have provided opportunities for musical expression using music technology through the school curriculum.

The project engages Indigenous Australian students using a digital audio production system that allows them to use their personal, social and cultural identities to make meaningful creative endeavors. The project trials newly emerging technology using iPads and the GarageBand software that has generative music and synchronization capabilities, to explore the development of self-confidence and self-esteem.

The approach involves the trialing of weekly music-based activities in several classes over two terms (20 weeks). The activities are design to offer opportunities for students to achieve creative educational goals, to engage them in expressive music-making, to develop self-esteem and to develop creative collaborations with peers. 
The project aims to provide evidence of a positive model for engaging school students in an interactive musicbased education program and for building confidence and resilience. Objectives of the project include, to:

- Trial and evaluate new generative music technology to explore improvements in engagement and connectedness between students and the education system.

- Build resilience and raise the levels of educational achievement and aspiration of Indigenous students.

- Identify positive models of music education and health promotion.

- Use music technologies to build a sense of belonging and connectedness within the school environment that is protective of mental and emotional wellbeing.

\section{Accessibility via mobile technologies}

A catalyst for this project is the availability of appropriate computing software and hardware for music making. Apple's iPad and GarageBand software have features that make the activities of this project much more accessible that they have previously been. The iPad's small size and touch interface make it easy for students to handle and easy for schools to accommodate. The GarageBand software utilizes 'smart instruments' and 'Apple loops' that simplify music production, and recording and editing tools that allow personalization and customization. The smart instruments provided a constrained performance environment that minimizes 'mistakes' and can be used in music education in a similar way that restricted acoustic instruments (such as small xylophones) have been in the past. The music clips (Apple loops) allow for a constructor-set approach to music making where students can combine these building blocks without needing (yet) the facility to make the clips from scratch. GarageBand's audio recording capabilities enable students to capture and edit their own voice and sounds for use in their productions. The iPads and GarageBand combination support collaboration by allowing students, each with an iPad, to synchronize their music making over a local network. This activity, which we have previously called network jamming, facilitates groups of students to perform together. Finally, the ability of the software to record the music they compose and export files for later review and distribution, means that student's work can be available for reflection and or sharing with the wider community.

\section{Meaningful Engagement}

The theory of meaningful engagement was developed by Andrew R. Brown and Steve Dillon [3] (2012) and has underscored the development of network jamming research more broadly. It involves two dimensions. Musical engagement includes various creative behaviors, or ways of being involved in music. The modes of engagement outlined in the theory cover a range of interactions from listening and appreciating, to creating, performing and leading. The theory suggests that meaning can arise from engagements with music in three contexts; personal, social and cultural. That is, music can be personally satisfying, it can lead to positive social relationships, and it can provide a sense of cultural or community identity. Below is a summary of the modes of engagement and contexts for meaning.

\subsection{Modes of Creative Engagement}

- Appreciating - paying careful attention to creative works and their representations

- Evaluating - judging aesthetic value and cultural appropriateness

- Directing - leading creative making activities

- Exploring - searching through artistic possibilities

- Embodying - being engrossed in fluent creative expression 


\subsection{Contexts of Creative Meaning}

- Personal - intrinsically enjoying the activity

- Social - developing relationships with others

- Cultural - feeling that actions are valued by the community

The two aspects of meaningful engagement can be depicted as the axes of a matrix, as shown in figure 1.

\begin{tabular}{|c|c|c|c|c|c|}
\hline & Appreciating & Evaluating & Directing & Exploring & Embodying \\
\hline Personal & $\begin{array}{l}\text { Listen, } \\
\text { Read, } \\
\text { Watch }\end{array}$ & $\begin{array}{c}\text { Analyze, } \\
\text { Select }\end{array}$ & $\begin{array}{c}\text { Compose, } \\
\text { Produce }\end{array}$ & $\begin{array}{l}\text { Improvise, } \\
\text { Experiment, } \\
\text { Investigate }\end{array}$ & $\begin{array}{c}\text { Practice, } \\
\text { Play }\end{array}$ \\
\hline Social & $\begin{array}{c}\text { Share, } \\
\text { Recommend }\end{array}$ & $\begin{array}{l}\text { Discuss, } \\
\text { Comment }\end{array}$ & $\begin{array}{l}\text { Conduct, } \\
\text { Lead, } \\
\text { Instruct }\end{array}$ & Jam & $\begin{array}{l}\text { Rehearse, } \\
\text { Record }\end{array}$ \\
\hline Cultural & $\begin{array}{c}\text { Attend, } \\
\text { Patronize }\end{array}$ & $\begin{array}{l}\text { Curate, } \\
\text { Review }\end{array}$ & $\begin{array}{l}\text { Promote, } \\
\text { Manage }\end{array}$ & $\begin{array}{c}\text { Research, } \\
\text { Publish }\end{array}$ & Perform \\
\hline
\end{tabular}

Figure 1. The Meaningful Engagement Matrix with exemplar musical activities

The meaningful engagement matrix (MEM) is a framework for describing creative experiences and evaluating creative resources, plans or activities. For example, assessing a community or educational workshop, reviewing the comprehensiveness of an arts curriculum or lesson plan, evaluating the affordances of a software application for creating media content. While this matrix was developed for musical activities it can be applied to other pursuits, especially in the Arts.

Artistic experiences become meaningful when they resonate with us and are satisfying. The meaningful engagement matrix has been developed to assist inquiry into our creative activities and relationships. A full creative life, the theory suggests, involves experiences across all cells of the matrix. Therefore, this framework can be useful when auditing the range of experiences afforded by any particular activity, program or resource, or across a set/series of these. It is in the assessment of the whole-of-program view of this project that the MEM provides its greatest utility.

\section{Resilience}

Resiliency refers to the capacities within a person that promote positive outcomes such as mental health and wellbeing, and provide protection from factors that might otherwise place that person at increased developmental, social and/or health risk [4, 5] (Rowe \& Stewart, 2009; Fraser, 1997). Factors that contribute to resilience include personal coping skills and strategies for dealing with adversity such as problem-solving, cognitive and emotional skills, communication skills and help-seeking behaviors [5] (Fraser, 1997).

There is an abundance of research that highlights the importance of the social environment, or social relationships for fostering resilience [6, 4] (Maggi et al., 2005; Rowe \& Stewart, 2009). Social cohesion or connectedness refers to broader features of communities and populations and is characterized by strong social bonds with high levels of interpersonal trust and norms of reciprocity, otherwise known as social capital [7] (Siddiqui, et al., 2007). This network of rich social relationships and strong connections promote a sense of belonging and community connectedness which, in turn, impacts on an individual's mental health and overall well-being [8] (AIHW, 2009). Social capital, spirituality, family support and a strong sense of cultural identity are key protective factors for Indigenous people (and children) [9] (Malin, 2003).

Schools that aim to strengthen their capacity as healthy settings for living, learning, working and playing, and are underpinned by inclusive participatory approaches to decision-making and action, can help to build resilience [4] (Rowe \& Stewart, 2009). Connectedness in the school setting has been shown to be a protective factor of adolescent health risk behaviors related to emotional health, violence, substance use and sexuality. Creative activities, especially 
collaborative ones such as music making, share many of the characteristics that have been shown to promote resilience. This project seeks to take advantage of these connections.

\section{Collaboration and Sustainability}

With relevant support from the Murri school community, the project offered the opportunity to develop a creative and sustainable program for young people, in this case young Indigenous Australians, to engage in collaborative music making activities using interactive music technologies. The reason that music technology is appropriate for the project was because of its familiarity to young people and also because of our expertise in the use of generative systems in collaborative music making.

A number of creative projects use music jamming as a means of improving creativity, social justice and wellbeing, hence there are many collaborations with communities that are sometimes marginalized from mainstream society [10] (Adkins et al. 2012). The GarageBand software for the iPad supports collaborative audio production through local synchronization via Bluetooth and through file and audio material export and import. When used as a musical instrument and compositional platform this software enables students to build on basic skills of exploration and improvisation and encourages engagement. These technologies are also easy for staff to learn and use and this, it is hoped, will increase the likelihood that the network jamming activities will continue in the school beyond the life of this project. A number of strategies were used to facilitate the sustainability of the activities. These include:

- Involvement of school administration and teaching staff in the planning and execution of the activities.

- Integration of the music activities into the broader curriculum.

- Sharing of the musical outcomes amongst the school community.

- Regular reporting on progress with the school administration.

- Provision to leave the equipment used for the project with the school.

\section{Case Study - iPads and Music at the Murri School}

The goal of the project was to examine how music technology can work to improve Indigenous health and wellbeing by creating a sustainable program for Indigenous youth to engage in collaborative music making activities using interactive music technology.
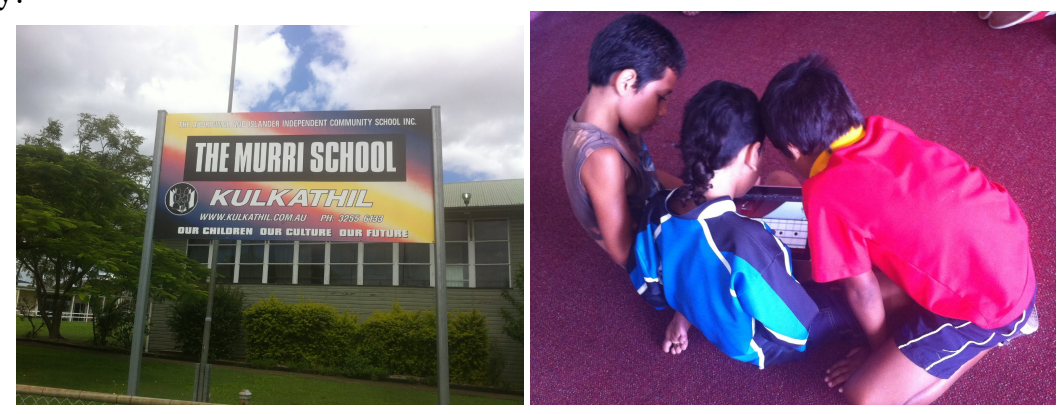

Figure 2. Images from the project school

The project integrated music activities using the iPad into the normal school curriculum and involved relevant teachers. It used standard classroom procedures and resources but the project provided a facilitator proficient in the technologies and familiar with theories and objectives of the project. The project involved a weekly session with each class facilitated by a member of the project team and the class teacher.

Prior to commencing, teachers and students were provided with information about the project and teachers were consulted about how the music-based activities might integrate with existing curriculum objectives. Many teachers chose to incorporate creative writing tasks as the basis for song writing and rapping. The project used a whole-school approach and classes were chosen from across the full age range of the school for participation. Students and teachers 
were not screened for musical background nor on any measure of resilience as we were keen to investigate the versatility and flexibility of this approach across the school community.

After consultation with staff, three grade levels were selected to participate in the project. The year levels and project summaries for these classes are summarized in the following table.

Table 1. Participating Groups and Activities

\begin{tabular}{|c|c|l|}
\hline Year Level & Approx. Age & Activity Objective \\
\hline $2 / 3$ & $7 / 8$ & $\begin{array}{l}\text { Students to write and record a short 4-line rap about } \\
\text { the good qualities they see in themselves }\end{array}$ \\
\hline 4 & 9 & $\begin{array}{l}\text { Students to record a creative interpretation of their } \\
\text { sonic personal profiles utilizing sounds and music } \\
\text { to express their personalities. }\end{array}$ \\
\hline 8 & 13 & $\begin{array}{l}\text { Students to write and record a sonic poem using text } \\
\text { and music describing themselves and their hopes, } \\
\text { expectations and dreams. }\end{array}$ \\
\hline
\end{tabular}

\subsection{Designing music-based activities}

Prior to facilitating the intervention with the students at the Murri school, a series of generic activities were designed with a view to facilitating creative participation in a way that adheres to the philosophy interwoven in the aforementioned MEM framework. These were used as a resource to stimulate activity design and lesson planning during the project. The key objectives of the music-based activities designed for this project were to: 1) enable the students to engage in diverse music making opportunities that utilize music technology in a meaningful way; 2) to enable participants the opportunity to engage in creative experiences that assist in positively strengthening their sense of well being and resilience.

Based on these resources, activities for each year level were collaboratively developed by the researchers and participating class teachers; keeping the MEM in mind throughout this process. Each teacher chose to utilize an age/ability-appropriate literacy basis for their class project in order to facilitate the opportunity for students to individually and collectively express themselves and their interests in a personal and creative manner.

The objective for Term 1 was to enable students of each participating group to develop and record their own composition using GarageBand on the iPads. The timeline below outlines the context of each weekly session dedicated to the project, allowing for students of each group to spend time experimenting, jamming, practicing playing and recording instruments and external audio, and for recording the final product. The objective for Term 2 was for students to develop and refine their work into a form ready for a 'signature' event-a public performance at the school assembly.

Table 2 lists the mode and context of activities designed to achieve the key objectives of this project. Each cell corresponds to specific mode and context combination within the MEM.

Table 2. Project activities across the Meaningful Engagement Matrix.

\begin{tabular}{|l|l|l|l|l|l|l|}
\hline & & $\begin{array}{l}\text { ATTENDING } \\
\text { Listening / Ob- } \\
\text { serving }\end{array}$ & $\begin{array}{l}\text { EVALUATING } \\
\text { Reflecting / Ana- } \\
\text { lyzing }\end{array}$ & $\begin{array}{l}\text { EXPLORING } \\
\text { Experimenting / } \\
\text { Improvising / } \\
\text { Conscious }\end{array}$ & $\begin{array}{l}\text { DIRECTING } \\
\text { Decision Making / Instructing }\end{array}$ & $\begin{array}{l}\text { EMBODYING } \\
\text { Playing / Performing / } \\
\text { Establishing habits }\end{array}$ \\
\hline $\begin{array}{l}\text { PERSONAL } \\
\text { (Of the self) }\end{array}$ & Objective & $\begin{array}{l}\text { Independently } \\
\text { listen, read } \\
\text { and } \\
\text { observe in or- } \\
\text { der } \\
\text { to become } \\
\text { aware } \\
\text { of relevant } \\
\text { knowledge. }\end{array}$ & $\begin{array}{l}\text { Independently } \\
\text { reflect and } \\
\text { analyze personal } \\
\text { practice as a } \\
\text { means of } \\
\text { facilitating } \\
\text { continued } \\
\text { learning. }\end{array}$ & $\begin{array}{l}\text { Independently } \\
\text { explore and } \\
\text { experiment with } \\
\text { relevant artefacts } \\
\text { and processes. }\end{array}$ & $\begin{array}{l}\text { Engage in } \\
\text { technical } \\
\text { activities that lead to creating a } \\
\text { musical artefact. }\end{array}$ & Independent \\
practice / playing.
\end{tabular}




\begin{tabular}{|c|c|c|c|c|c|c|}
\hline & Activity & $\begin{array}{l}\text { Introduction } \\
\text { to } \\
\text { Network } \\
\text { Jamming. } \\
\text { Demonstration } \\
\text { of available } \\
\text { interactive } \\
\text { music } \\
\text { hardware and } \\
\text { software. }\end{array}$ & $\begin{array}{l}\text { Record/journal } \\
\text { learning and } \\
\text { practical } \\
\text { experiences. } \\
\text { Music analysis } \\
\text { to enable the } \\
\text { development of } \\
\text { aural skills. }\end{array}$ & $\begin{array}{l}\text { Independently } \\
\text { explore and } \\
\text { experiment with } \\
\text { sounds and } \\
\text { functions of } \\
\text { Network Jam- } \\
\text { ming } \\
\text { devices. Build- } \\
\text { ing } \\
\text { knowledge. }\end{array}$ & $\begin{array}{l}\text { Setting up a Jam session. } \\
\text { Composing a song. }\end{array}$ & $\begin{array}{l}\text { Guided and } \\
\text { Independent } \\
\text { Play / Practice of Network Jamming } \\
\text { devises and } \\
\text { processes to } \\
\text { building skills. }\end{array}$ \\
\hline \multirow[t]{2}{*}{$\begin{array}{l}\text { SOCIAL } \\
\text { (Collaborative) }\end{array}$} & Objective & $\begin{array}{l}\text { Share work } \\
\text { and } \\
\text { progress with } \\
\text { peers. }\end{array}$ & $\begin{array}{l}\text { Reflect upon } \\
\text { learning and } \\
\text { practical } \\
\text { experiences with } \\
\text { peers as part of } \\
\text { group discus- } \\
\text { sions. }\end{array}$ & $\begin{array}{l}\text { Extend learning } \\
\text { through } \\
\text { collaborative } \\
\text { experimentation. }\end{array}$ & $\begin{array}{l}\text { Take on a } \\
\text { leadership role } \\
\text { within a group } \\
\text { activity. }\end{array}$ & $\begin{array}{l}\text { Rehearse and } \\
\text { record with a } \\
\text { group. }\end{array}$ \\
\hline & Activity & $\begin{array}{l}\text { Workshop } \\
\text { presentations } \\
\text { of } \\
\text { individuals } \\
\text { and } \\
\text { collaborative } \\
\text { engagement } \\
\text { and } \\
\text { progress with } \\
\text { Network } \\
\text { Jamming. }\end{array}$ & $\begin{array}{l}\text { Group Discus- } \\
\text { sion. }\end{array}$ & $\begin{array}{l}\text { Engage in a } \\
\text { group (Net- } \\
\text { worked) Jam } \\
\text { session. }\end{array}$ & $\begin{array}{l}\text { Lead and Conduct a Jam Session. } \\
\text { Group Composition. }\end{array}$ & $\begin{array}{l}\text { Time to } \\
\text { play/practice with Network Jamming } \\
\text { devices and } \\
\text { processes } \\
\text { collaboratively. }\end{array}$ \\
\hline \multirow[t]{2}{*}{$\begin{array}{l}\text { CULTURAL } \\
\text { (Connection } \\
\text { with external) }\end{array}$} & Objective & $\begin{array}{l}\text { Observe rele- } \\
\text { vant } \\
\text { activity as } \\
\text { performed in a } \\
\text { public context. }\end{array}$ & $\begin{array}{l}\text { Extend and } \\
\text { connect reflec- } \\
\text { tive } \\
\text { practice to } \\
\text { include a wider } \\
\text { cultural partici- } \\
\text { pation and dia- } \\
\text { logue. }\end{array}$ & $\begin{array}{l}\text { Examine / } \\
\text { research relevant } \\
\text { practice in a } \\
\text { wider cultural } \\
\text { context. }\end{array}$ & $\begin{array}{l}\text { Support and } \\
\text { promote a } \\
\text { musical artefact for public } \\
\text { distribution. }\end{array}$ & $\begin{array}{l}\text { Participate in a } \\
\text { group public } \\
\text { performance. }\end{array}$ \\
\hline & Activity & $\begin{array}{l}\text { Attending / } \\
\text { Observing a } \\
\text { performance } \\
\text { that } \\
\text { utilizes Net- } \\
\text { work } \\
\text { Jamming as a } \\
\text { key composi- } \\
\text { tion / perfor- } \\
\text { mance pro- } \\
\text { cess. }\end{array}$ & $\begin{array}{l}\text { Develop a crea- } \\
\text { tive } \\
\text { project for pub- } \\
\text { lic } \\
\text { presentation. } \\
\text { Create a } \\
\text { Blog/website as } \\
\text { a reference for } \\
\text { music work. }\end{array}$ & $\begin{array}{l}\text { Investigating } \\
\text { Network Jam- } \\
\text { ming } \\
\text { in diverse } \\
\text { cultural } \\
\text { contexts. } \\
\text { Explore other } \\
\text { commercial } \\
\text { music apps. }\end{array}$ & $\begin{array}{l}\text { Create and } \\
\text { promote a } \\
\text { CD/DVD } \\
\text { showcasing } \\
\text { creative progress. }\end{array}$ & $\begin{array}{l}\text { Perform a group } \\
\text { 'Jam' or } \\
\text { composition to an audience. }\end{array}$ \\
\hline
\end{tabular}

\subsection{Measuring resilience and engagement}

Evaluation of this project relied on a mixed methods research design combining quantitative and qualitative methods of data collection, analysis and inference in order to investigate both the processes developed through the life of the project as well as the impact of the project over time.

Students were asked to complete a modified version of a pre-existing resilience questionnaire that has high levels of reliability and validity [11] (e.g., Healthy Kids Survey - California Dept of Education, 2004). Key informant interviews with staff were conducted and subject to an ongoing thematic analysis. An introductory school consultation session was attended by 9 staff members at the outset of the project. All were supportive and identified ways that they could integrate the project into their curriculum. Due to timetabling constraints only three of these staff and their classes participated in the project.

Thirty four students participated in the project across three grade levels: Years 2/3 (14 students); Year 4 (12 students); and Year 8 (8 students in the English stream). Activities included developing a Rap, recording a personal sonic profile and writing and recording a bio-poem. Observations of class sessions were recorded in a journal by a member of the research team. In addition, files of work completed on the iPad were regularly saved allowing for analysis of the steps taken during the creative process. 


\section{Survey results summary}

The first stage of data collection provided a baseline and descriptive statistics show some differences between the younger students in Grade 2/3 and 4 and their fellow students in Grade 8. We have not completed tests of statistical significance as the sample is small. We provide, below, a selection of the results and findings. First we provide a summary with some data from the first resilience survey, conducted prior to the students participating in the activity, to give a sense of the student's attitudes and expectations from the project.

Over $75 \%$ of the total student sample thought that being involved in the project would be fun and most (younger students) were excited at the prospect. The creative levels and aspirations of the students were uniformly high and almost all indicated that they enjoyed going to music performances. However, compared to the grade 2/3 and 4 students who relished the creative opportunities of the project, a substantially lower percentage of the Grade 8 sample felt confident and supportive of the activity and their creative role.

With regard to their confidence with and support structure for creative activities:

- Over $85 \%$ of all students like making things that are creative and different.

- Students felt variously confident with their own creative ability and ideas. (71\% of Grade 2/3, over $90 \%$ of Grade 4 students, Grade $8=63 \%$ ).

- Most students have family/elders that they can go to for help (Grade 2/3=79\%, Grade $4=90 \%$, Grade $8=75 \%$ )

The students' attitudes toward peer collaboration varied between the younger and older students. The following data reflect these attitudes to working with classmates:

- Students like to share their creative ideas with their classmates (Grade 2/3=78\%, Grade $4=90 \%$, Grade $8=37 \%$ ).

- Students enjoy hearing about their classmates' creative ideas (Grade 2/3 82\%, Grade $4=\% 85$, Grade $8=63 \%$ ).

- Students thought that being a part of the project would help them have more friends (Grade $2 / 3=75 \%$, Grade $4=$ $75 \%$, Grade $8=12 \%$ ).

As with attitudes to collaboration, the students' sense of self-confidence in public music making also reduced with age. In relation to producing a performance or recorded outcome:

- Students thought that they could put together a performance or recording that would be enjoyed by others (Grade $2 / 3$ $=86 \%$, Grade $4=66 \%$, Grade $8=12 \%$ ).

- Students felt that people would come to watch their performance or record launch (Grade $2 / 3=90 \%$, Grade $4=$ $75 \%$, Grade $8=25 \%$ ).

A clear trend in this data is the difference in reported self-confidence, in music at least, between the younger (7-9 year old) and older (13 year old) students. This is consistent with much more extensive research that shows a dip is selfconfidence in adolescents [12] (Orenstein 1994). As a result of this, and supported by informal feedback from the grade 8 teacher, we adopted a different strategy for the older group. Activities for this class focused more on personal meaning than on social or cultural meaning, and we tried to minimize potentially embarrassing public presentations of the music. As well, work for older students has a greater individual focus whereas activities for younger students are heavily biased toward group work and include class and public presentation of outcomes in the form of recorded media and live performance. What is interesting to note, is that the accessibility features of the music technologies employed are equally applicable for both groups and approaches.

\section{Qualitative results summary}

Qualitative data included interviews conducted with teachers, notes maintained by research team members and samples of media produced by participants. The research team utilized the Meaningful Engagement Matrix to record the frequency and intensity of meaningful engagements they observed in students participating in the project. Video footage and photography were also being used to provide further documentation of project implementation activities, and for review and analysis. 


\subsection{Pre-intervention results}

Staff members recorded their initial plans for implementing the project within their classrooms for Term 1 and Term 2, 2013. Eight out of the nine staff members participated in this component of the staff session. Participant responses to what they hoped to achieve by being involved in the project include:

- For the students to record stories created for English unit. The story can be edited and compiled onto a CD. Hopefully children will gain confidence in speaking and sharing their stories/ideas.

- I would like to see students engage with iPad technology to enhance and extend learning already happening in subjects.

- Improve teacher and student confidence and participation with technology; having children work together cooperatively; tap into children's different learning styles i.e. rap songs to learn spellings; student enjoyment.

- To use the jamming as a learning/teaching tool in classroom - to integrate curriculum to make learning fun.

- To learn myself and get children involved in expressing themselves orally and musically.

- To record for a performance, to make learning fun and for students to use an iPad.

- Enhancement of student work (oral and written) - familiarity with technology.

- Increase iPad literacy, learn with students how to use this tool for work.

\subsection{Post-intervention results}

\section{Classroom management}

In terms of general process, the participating classroom teachers had differing opinions regarding how manageable it is to have a class of students work with the iPads for engaging in learning and collaborative work. Two of the teachers felt that this was a manageable task, whereas one of the teachers (Grade 4) felt that this process of learning would work best in smaller groups as children may have difficulty listening to instructions and paying attention in a larger group. Some of the challenges in participating in the project include student's inability to share iPads - they preferred to work on their own. Another challenge lay in having a consistent and clear idea of the long-term goal and clarifying goals for students to be achieved at the end of each session.

One teacher felt that at times it seemed that the students were 'all over the place'. This was due to the students showcasing their ability to 'jam' on the iPads using different musical instruments available on GarageBand. Jamming with colleagues allows for creative expression that relies on self-expression. The grade 4 teacher felt that not being present regularly, and not understanding how to use the iPads and remembering it were challenges. Also, keeping all the students on task when the whole class was involved was a challenge. She felt that keeping the iPad project in a small group environment might assist in overcoming some of these challenges.

However, in terms of how satisfied the teachers were with the way the project had been implemented in their class, there was general consensus that they felt that the project went well and that the students looked forward to the sessions on the iPad.

\section{Student engagement}

Observational notes and a review of the media outcomes, reveal that students engaged in a variety of ways consistent with the spread of modes in the MEM. However, as might be expected, the depth of engagement varied between individuals and within individuals over time. For example, some of the year 8 participants took an extended time to develop material for their sonic poems but regained enthusiasm when this material was combined with semi-automated backing tracks for the recorded outcome at the end of the first stage. By way of contrast the younger classes started with a great deal of enthusiasm, were only moderately interested in the recorded outcome, but were very enthusiastic in the second half of the project that focused on a performance outcome. 
The Grade 2 teacher was really impressed that his more challenging students, who rarely engaged in classroom activities, were able to participate confidently in the project. Those that had difficulty with directing their attention to one specific task for a period of time were able to participate in the iPad sessions for the course of the weekly schedule.

The Grade 8 teacher felt that he under-estimated the students' reluctance to share their work. He felt that his lack of knowledge of technology/iPads required increased reliance on the project facilitators. He acknowledged that the students had a product at the end of the project, but considered that the iPads could have been better used.

\section{Teacher engagement}

The Grade 4 teacher felt that there were components of the program that she liked and some parts of the program she did not find helpful in making the project run smoothly. Teacher ownership is a critical success factor for the sustainability of the project. She felt that because she wasn't there most of the time for the weekly iPad sessions, she found it difficult to gauge how effectively the implementation was going. She indicated that there were times when it was confusing what the object of the lesson was. This reinforced the importance of working with the teachers to develop an action plan for their students and take a leadership role in achieving their goals and objectives.

The participating teachers relied on the project facilitator to set weekly plans for the students, offering limited guidance and support. Behavior management was a challenge each week for the facilitators. Often teacher aides were the only other adults present to provide additional supervision for the children and at times sessions were taken up with disciplining students.

\section{The 'signature' event}

The grade 4 teacher stated that he enjoyed watching those children who performed on assembly and that, in the end, the project performance sounded good. He stated that some of the students are normally really shy and would never get up on their own. But, because they were in a group and focusing on the iPad they coped.

All teachers stated that they were happy with what their class had achieved by participating in the project. The Grade 8 teacher stated that hopefully they will have greater confidence to use technology to support English language leaning with music-based activities.

\section{Findings}

This project applied the practices of network jamming and the use of the meaningful engagement matrix (MEM) to the use, for the first time by these researchers, of commercial software in the form of Apple's GarageBand for the iPad in a school setting. There was a particular focus on the use of musical activities to support student resilience. Overall the application of these mobile technologies was successful both practically in providing ease of access and in allowing for the range of meaningful engagements outlined in the MEM.

The technologies supported private, social and public music making practices. These were applied to varying degrees as seemed appropriate to student's levels of confidence and capability. For some students their focus was on private creative expression, others worked collaboratively in networked classroom situations, and some students participated in a public concert of original works using the technology.

Observational analysis showed that students were able to engage in activities that involved various modes of engagement, from listening, to exploring, creating, and performing. The cross-curricular integration of musical tasks, especially to support language development and expression was well received by students and teachers. While there was no formal measure of an increase in resilience, the adaptability of the pedagogical approach to suite a wide range of personality types and degrees of confidence was noted by teachers and facilitators.

All teachers considered that their involvement in the project has made a difference to the way they have looked at teaching. The grade 4 teacher stated that it gave her another avenue through which to teach. Technology is the focus of our learning now, she said. The grade 8 teacher stated that it has highlighted a need to use technology in the class. Students have access to it outside of school they use it all the time-it is a tool he feels he needs to tap into for learning. All participating teachers have plans to continue to use this form of learning for future teaching. 
The project indicates that it is beneficial to have a structure around using the iPads in class. To start with structure was thought to be important i.e., weekly plan/within a subject. The grade 8 teacher felt that freedom to be creative can flow on from this.

Indicators are that the project had had a positive impact on the students. The Grade 8 teacher stated that the students looked forward to 'Friday' sessions. He stated that although they were shy, he believes that they were secretly proud of what they did. The Grade 4 teacher said that they loved it and looked forward to it. She also said that she could use the iPads as a reward for good behavior.

All teachers stated that they would recommend using the iPads as an approach to learning to other teachers. The Grade 2 and 8 teachers felt confident in sharing this approach to learning with colleagues. All teachers felt that they would have liked more professional development on using the iPads.

\subsection{Lessons learnt}

This project aimed to examine how music technology can work to improve student health and wellbeing. The project aimed to offer the opportunity to develop a creative and sustainable program for young Indigenous Australians to engage in collaborative music making activities using interactive music technologies. The following lessons have been learned from this pilot project:

- An in-class project of this nature requires relevant support from the whole Murri school (Indigenous) community.

- A planned period of in-service training and support with the teachers would help to ensure that the project is introduced with confidence and becomes sustainable beyond the life of the project.

- Small group work with all students accessing the technology would ensure better student engagement.

- A clear link between curriculum frameworks and the use of iPad technology helped to engage the project within the School's learning community.

- Students enjoy and engage with mobile media technologies within the classroom and can develop meaningful experiences through personal and social creative expression.

- The Meaningful Engagement Matrix provides a strong theoretical framework for planning a school-based creative project. Further data analysis might also confirm its utility for analysis of student behavior and experience.

- Additional research is needed to confirm the reliability and validity of the questionnaire with consideration given to a range of instrument structures to allow for widely varying age/developmental conditions.

- This project provided a constructive and stimulating experience for many young people, even those who find group work difficult and have communication difficulties.

- Public performance of creative, music-based projects provide important opportunities to enhance self-esteem and promote creative partnerships.

\section{Conclusion}

In this paper we have described our use of mobile technologies and software to make music-based activities accessible to young people in a way that promotes meaningful engagement and resilience. The project was based in the Murri school in Brisbane, Australia that is dedicated to the education of Indigenous Australians. The project involved weekly activities with three classes from that school over 20 weeks with students ranging from ages 7-13.

The design of project activities was informed by theories of meaningful engagement and resilience, but were guided by the advice of class teachers and student survey responses to ensure appropriateness to the local context.

Data indicate that staff and students are enthusiastic about using the tablet computers and music apps, and that their ease of use is making previously unimagined music production activities accessible. Consistent with other studies, our data shows a dip in the creative self-confidence of students in their early teens (compared to younger students). This has been accommodated for by shifting the emphasis for those students toward individual and personal expression and away from collaborative and public activities.

The portability of the iPad hardware has assisted with the integration of the devices into the school environment, and their multi-purpose nature makes for fluid shifts between music and other curricular tasks (such as creative 
writing). The GarageBand software has facilitated rich music production outcomes, although the devices alone provided limited audio recording and playback quality. We plan to address this in any future projects through more extensive use of external microphones and headphones.

Indications are that the students can be keenly engaged in network jamming activities but require an ongoing facilitator support to maximize creative outcomes. The features of the music-based activities with ubiquitous technologies align well with characteristics that promote resilience, including personal autonomy and connectedness with peers and adults, and we remain optimistic that evidence of a positive effect on student resilience from the project can be achieved.

\section{Acknowledgements}

We would like to thanks the staff and students of the Murri school for their participation in this project. The project was supported by the Queensland Centre for Social Science Innovation. We'd like to acknowledge the vision and enthusiasm of the late Steve Dillon who instigated this project but, unfortunately, was not able to be part of its realization.

\section{References}

1. Brown, A. R., \& Dillon, S. (2007) "Networked Improvisational Musical Environments: Learning through online collaborative music making”. In: J. Finney \& P. Burnard (Eds.), Music Education with Digital Technology, pp. 96-106. London: Continuum.

2. Stewart, D., Jing, S., Patterson, C., Lemerle, K., \& Hardie, M. (2004) "Promoting and building resilience in primary school communities: evidence from a comprehensive 'health promoting school' approach". International Journal of Mental Health Promotion, 6(3), 26-33.

3. Brown, A. R., \& Dillon, S. (2012) "Meaningful Engagement with music composition". In: D. Collins (Ed.), The Act of Musical Composition: Studies in the creative process, pp. 79-110. Surrey, UK: Ashgate.

4. Rowe, F., \& Stewart, D. (2009) "Promoting Connectedness through Whole-School Approaches: A Qualitative Study". Health Education, 109: 5, $396-413$

5. Fraser, M.W. (1997) Risk and Resilience in Childhood. USA: NASW Press

6. Maggi, S., Irwin, L. G., Siddiqi, A., Poureslami, I., Hertzman, E., \& Hertzman, C. (2005) Knowledge Network for Early Child Development. British Columbia: World Health Organisation.

7. Siddiqi, A., Irwin, L. G., \& Hertzman, C. (2007) "Total Environment Assessment Model for Early Child Development". www.who.int/social_determinants/.../ecd_kn_evidence_report_2007.pdf. Retrieved 20.05.10

8. AIHW (Australian Institute of Health and Welfare). (2009) A Picture of Australia's Children: Health and Wellbeing of Indigenous Children. Canberra: AIHW.

http://www.aihw.gov.au/

9. Malin, M. (2003) Is Schooling Good for Aboriginal Children's Health? Northern Territory University: The Cooperative Research Centre for Aboriginal and Tropical Health.

10. Adkins, B., Bartleet, B.-L., Brown, A. R., Foster, A., Hirche, K., Procopis, B., Ruthmann, A., \& Sunderland, N. (2012) "Music as a tool for social transformation: A dedication to the life and work of Steve Dillon (20 March 1953 - 1 April 2012)". International Journal of Community Music, 5(2), 189-205.

11. California Healthy Kids Survey. (2004) California Department of Education (Safe and Healthy Kids Program Office) and WestEd (Health and Human Development Department).

12. Orenstein, P. (1994) Schoolgirls: Young women, self esteem, and the confidence gap. Anchor Press. 